\title{
工具与高山景观:
}

一种调查贡嘎山路线的方式

\section{TOOLS AND ALPINE LANDSCAPES: AN APPROACH TO INQUIRING INTO MOUNT GONGGA ROUTES}

李宾 挪威奥斯陆建筑与设计学院城市与景观学系设计课导师, 博士研究员

LI Bin Studio Instructor, PhD Research Fellow, Institute of Urbanism and Landscape,

Oslo School of Architecture and Design

Postboks 6768

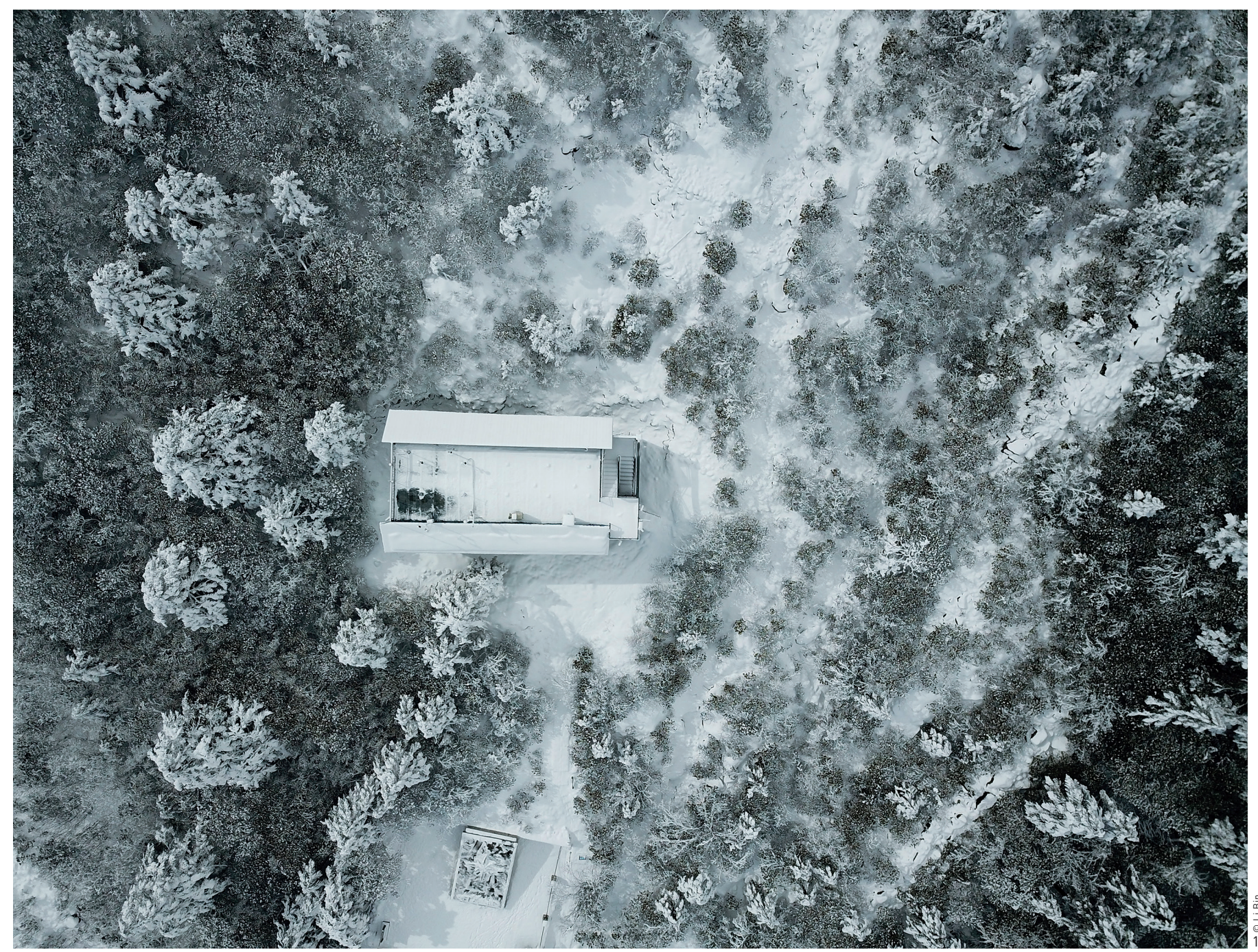

设计课程在海拔3 $600 \mathrm{~m}$ 处观察贡嘎山高海拔冰 川区的地貌、气象站、 观景栈道及平台、索道 交通与冰川河道。

The design studio

traveled to Mount

Gongga and at an

elevation of $3,600 \mathrm{~m}$

observed glacial

geomorphology,

weather station, scenic

path and platform,

and glacial river. 
https.//doi. org/10.15302/J-LAF-20180513

收福时间 RECEIVED DATE / 2018-08-16

中图分类号 / TU98

文献标识码 / A

摘要

中国的高寒山区曾经是地图上的未知之地, 这其中就包 括贡嘎山一高于成都平原7 $000 \mathrm{~m}$ 的横断山脉的最高峰。 贡嘎山正在经历着访客的剧增、基础设施的更新，以及路线 的重塑, 成为在城乡转型背景下探讨如何通过策划高山景观 路线与停卯场所来应对未来变化的一个典型区域。由于地

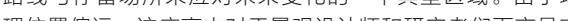

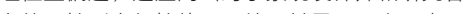
白的。地形突起拉伸且压缩了其景观层次, 也干顶着田野观 察。在挪威奧斯陆建筑与设计学院于特罗姆瑟市开设的景观 设计学硕士课程 “高处胜寒: 从北极地到极高山” 中, 师生 们尝试了一种混合的研究高山景观的方式: 以主题式的高山 绘图和田野工作框架为工具, 从挪威的高山区域入手调查了 贡嘎山。课程藉此对未来的停留场所和路线提出初步构想, 并在北挪威美术馆举办展览, 对这一跨地域的景观研究成果 进行了反思式的展示。

关键词

高山景观; 工具; 高山绘图; 田野工作框架; 策划; 景观路线

\section{ABSTRAC}

Chinese high cold mountains had long been an undiscovered terrain on maps. One of them was Mount Gongga, the highest peak of the Hengduan Mountain Ranges, elevated seven

thousand meters above the Chengdu Plain. Mount Gongga has been experiencing visitor blooming, infrastructure updating, and route reshaping, making it a representative case study to examine how landscape routes and pauses can be curated for future changes in ongoing rural-urban transitions. Geographical remoteness keeps this high mountain a white spot to landscape architects and researchers. Topographic prominence stretches and condenses alpine landscape layers and intervenes field observations. "Trans-Alpine: From the Polar to the Peak", a Master of Landscape Architecture design studio at the Oslo School of Architecture and Design locating in Tromsø, experimented with an approach to inquiring into Mount Gongga from Norwegian alpine zones: a combination of research tools including thematic alpine mapping and fieldwork framework. The tool outcomes informed the landscape researchers to further imagine future pausing or route scenarios. Some of the results were curated in an exhibition space at the Nordnorsk Kunstmuseum, as a reflective display of this landscape exploration across two

Keographies.

Alpine Landscape; Tool; Alpine Mapping; Fieldwork

Framework: Curating: Landscape Route

整理 王胤瑜陆小㻢

译 李宾

EDITED BY WANG Yinyu LU Xiaoxuan

TRANSLATED BY LI Bin

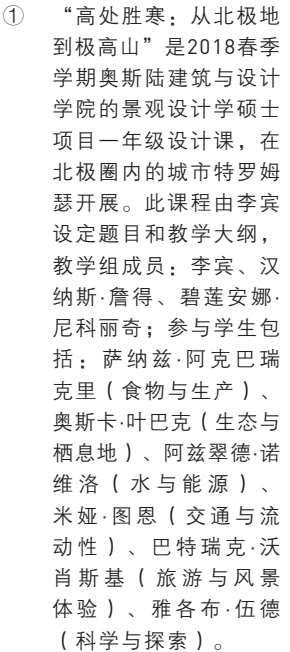

\section{1 课程概述}

在城乡转型中的中国有这样一类地理区 域，因极致且特别的地貌资源成为都市人群 的向往之地。它们从平原上拔地而起, 呈现 高山、极高山的形态, 并形成了多层的垂直 生态带和多样的文化景观。如今, 这类地理 区域的高山景观被视为资源, 赢得了越来 越多的关注 ${ }^{[1]}$ ，日渐繁荣的旅游文化推动 着当地基础设施的大规模更新, 本地乡村 与城镇逐渐转变为游鄎服务区, 区域景观 也因此变迁。中国西南地区的横断山脉里 存在着众多这样的高山区域，其中之一即是 位于四川省的海拔最高、地形最笽峻的贡嘎 山（图1）。

在奥斯陆建筑与设计学院 $(\mathrm{AHO})$ 于 挪威北部北极圈内的城市特罗姆瑟开展的景 观设计学课程 “高处胜寒: 从北极地到极高 山” (1) 中, 我们开始了对于贡嘎山的调查工 作。学生们作为外来研究者, 需要跨越地理 与地形上的障碍, 逐步了解这处 “空白” 的 中国高山区, 从而对其未来景观路线提出设 想。在课程中, 我们先从远方进行审视, 通 过对挪威高山区的绘图练习 (尤其是绘制横 断面图 ) 从不同角度来描绘并理解高山景观 的特质; 而后我们深入场地, 在各自田野工 作框架的指导下, 研究者们沿一条特定的贡 嘎山考察线路进行观察与景观体验; 最后,
根据上述过程提出设计构想，并在北挪威美 术馆以展览的形式呈现。

\section{2 高山的困难}

在《四川的高寒山》一书中, 绘图学 家爱德华·英霍夫这样写道: “雅聋江与大 渡河之间的贡嘎山是地图中 “尚未测绘” 的 空白区域; 有的地图在它的位置填上了臆想 的山景图。” ${ }^{[2]} 1930$ 年, 英霍夫作为中国 瑞士联合考察队的一员, 以地质测量与地图 制图为目的，携带着测量、记录工具行走在 环绕贡嘎的山谷、垭口之间。他选择了一条 距顶峰较近且海拔相对较低的环山测绘路 线一一此填补了这一地图上的“空白区 域”。80年后的今天，这条环山路线被开发 为一系列高架高速、风景公路、水电设施、 科研设施、冰川公园与旅游乡镇———种城 镇化的景观正在形成。

景观研究者从地图上获得的高山地理信 息是静态和 “精确” 的, 无法替代从田野工 作中习得的本地知识, 以及在行走中体会到 的个人与高山之间的张力; 身处高山之中， 研究者容易受到方位、视野、身体机能的干 扰与限制, 也经常因路径不通而绕行。高等 的山峰对景观层次同时进行了纵向拉伸和横 向压缩。从海拔1 $000 \mathrm{~m}$ 的大渡河干热河谷 到海拔7 $556 \mathrm{~m}$ 的永久积雪顶峰, 在 $30 \mathrm{~km}$
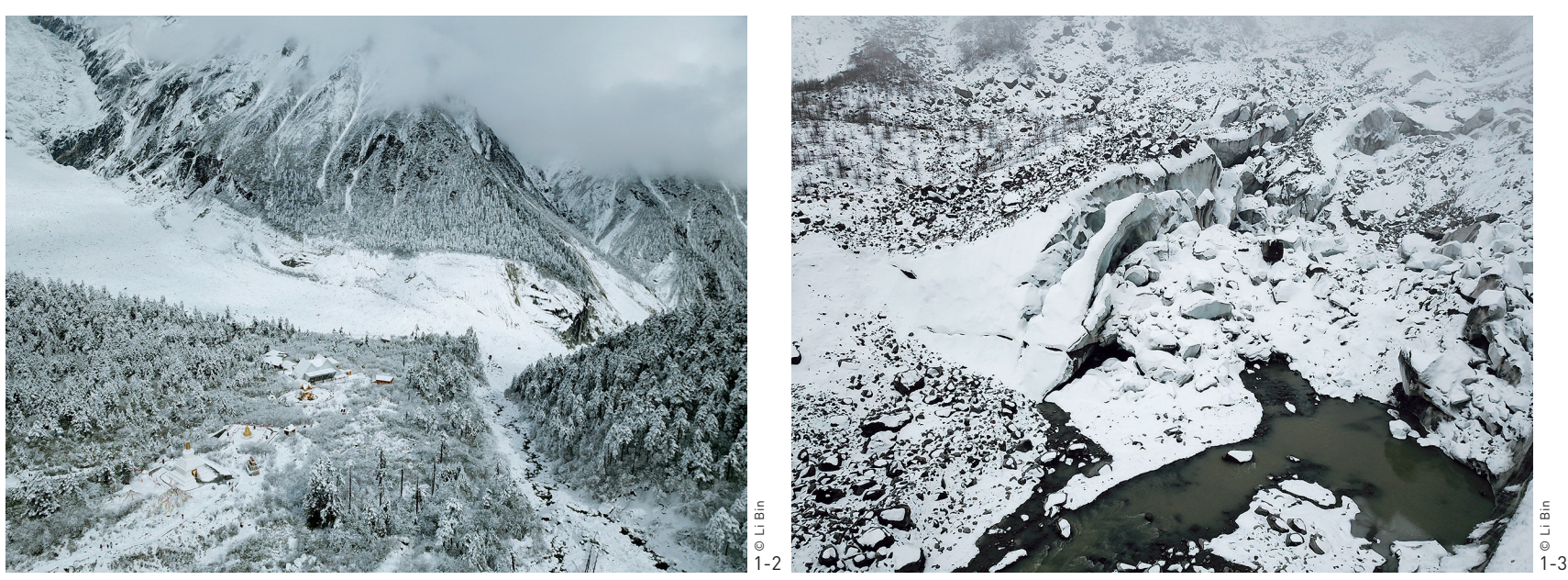


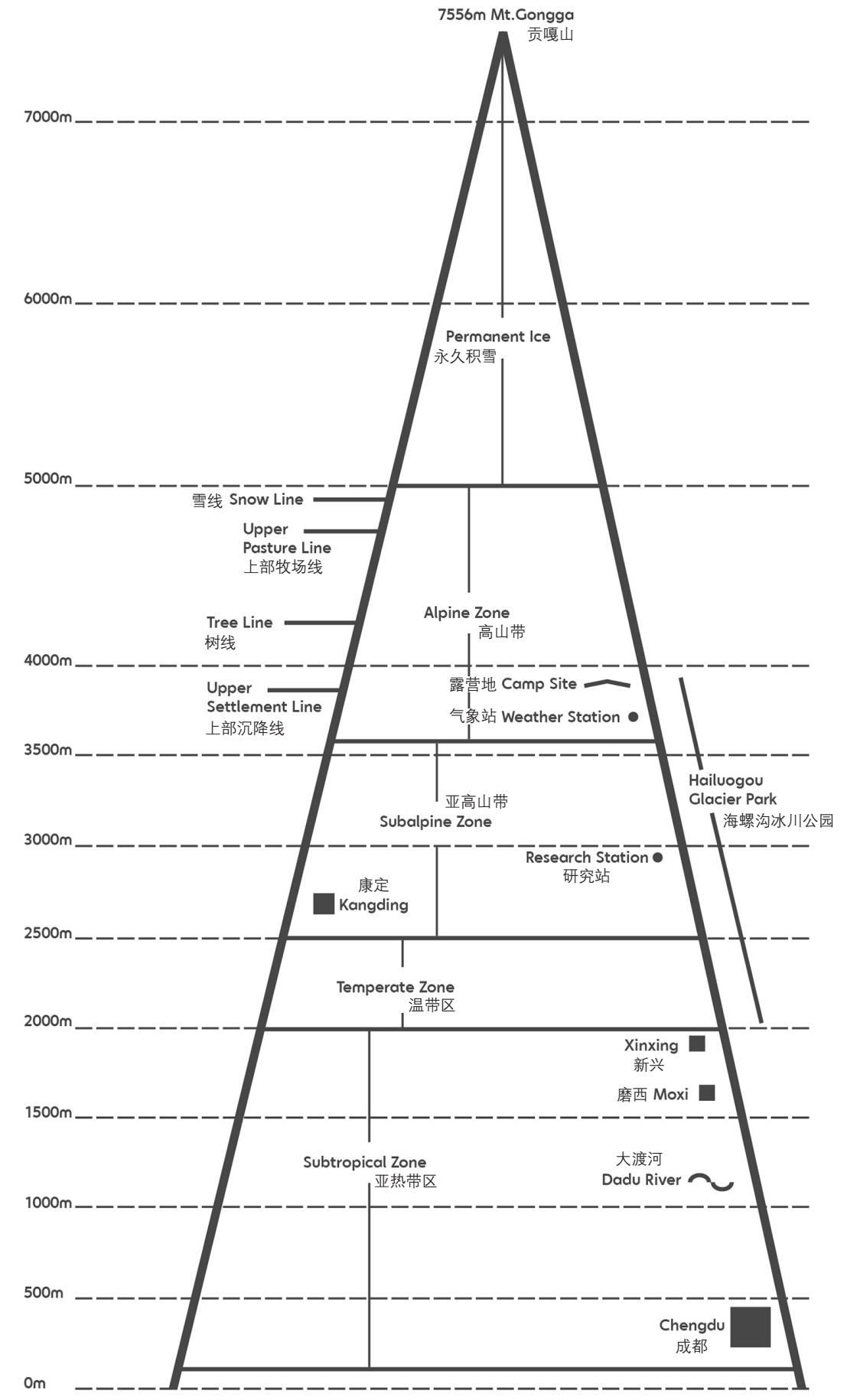

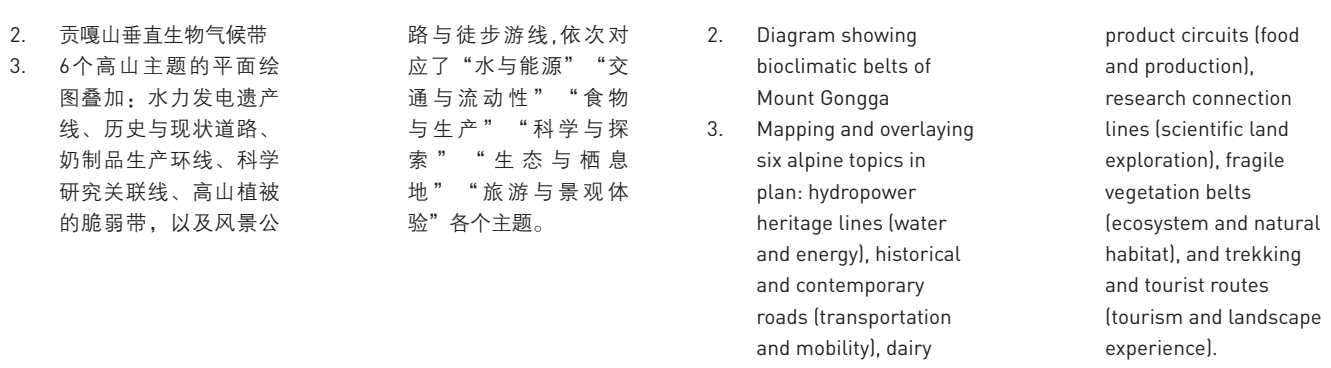

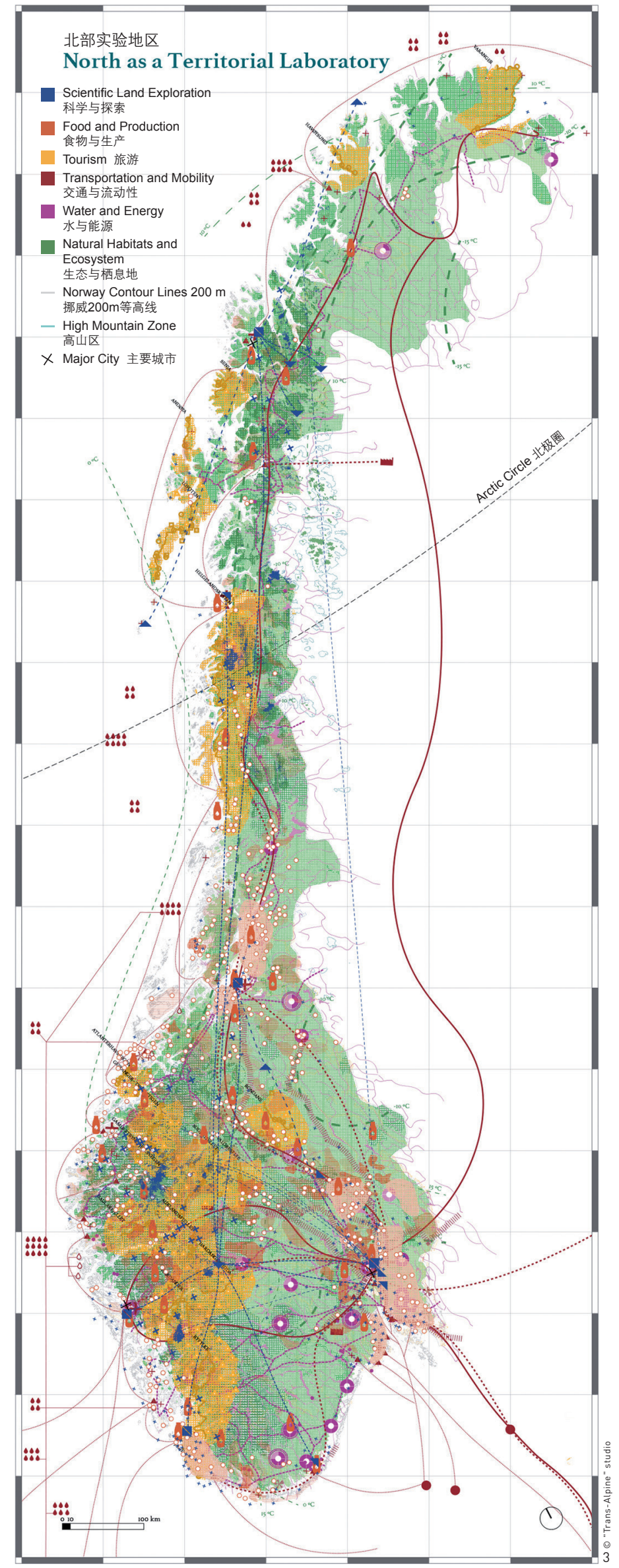


的直线距离内, 贡嘎山形成了从亚热带到寒 漠带的垂直生物气候带 ( 图2)。急剧变化 的地形, 折中的路线, 垂直发展的、相互交 叠且不断变化的景观, 将贡嘎这样的高山塑 造成一个相当复杂的研究对象。

\section{3 景观调查的工具}

“我们无法仅仅从视觉上或抽象上解 读人与景观之间的张力。因此, 通过将具象 与抽象的地理认知方式相结合, 我们可以更 加整体地评估个人与周遭环境的关系, 并觉 察到山地地形在人文环境与体验中的重要 性。”[3] 此次设计课程便尝试了一种调查 高山地区和贡嘎山的多重方式一一融合了远 距离观察与近距离调查、高山绘图与田野工 作, 以此作为景观表现与景观体验的工具。

地理学家丹尼斯 · 考斯格罗夫和韦罗妮 卡・迪拉多拉提出的 “高处/高地” 概念为跨 地域的高山研究提供了支持, 这一理论指出 高纬度和高海拔地区在气候、地貌、生态学 层面彼此参照, 且在文化地理学层面存在许 多 “复杂地区” 的共通特征 ${ }^{[4]}$ 。也就是说, 中国高山区域的诸多景观情景, 同样以相对 应的形态存在于挪威高山地区。将这些特征 进行主题分类, 可以帮助我们分层次地了解 高山景观。于是, 该设计课程分设了水与能 源、交通与流动性、食物与生产、科学与探 索、生态与栖息地、旅游与景观体验等6个 描述高山的主题。

课程首先在挪威进行了试验, 即运用平 面图与横断面图对上述主题进行描绘。我们 将挪威高山地区作为底图, 在上面描摹出地 域尺度的景观线（图3）。基于平面绘图, 每位研究者都要选取一段长 $20 \mathrm{~km}$ 的高山地 带, 绘制其横断面图以描述沿线的具体地 形、纵向空间与景观动态 (图4)。“这不 仅是空间表达方式的转变, 也要求设计者转 变思维观念以及审视空间关系的视角。平面 地图采取的是全局视角, 横断面图则是基于 一条线性路径绘制而成, 可能具有明显的方 向性。” ${ }^{[5]}$ 横断面图可以反映各类高山特征 的垂直组合情况、地表与地下过程, 以及景
观要素的时空变化。

在以绘图为工具探索区域尺度之后， 设计课程进入田野工作阶段。冈瑟·沃格特 在《珍奇癖 | 漫游屋》中将景观田野调查工 作总结为收集、记录与转译活动 ${ }^{2}$ 。与常规 书籍不同, 此出版物由卡片、折叠册、硬纸 板文件盒构成, 以此暗示田野工具的可能形 式。在漫游中收集到的田野知识, 先被记录 并归置于 “珍奇屋” 中, 然后转译为设计。 一个田野工作工具不只是一个媒介、设备或 器材, 而是一个经过设计的仪器或框架, 一 套以单一或多种媒介为基础的工作流程。作 为一种个人化、主观化的手段, 田野工具促 进了人们沉浸于景观之中或与之互动, 也有 助于构建理解特定景观环境与过程的信息体 系, 协助研究者应对田野考察中的种种变 化。实体工具应耐用且易于在野外环境下保 存。在该设计课程中, 研究者们需要确立工 作思路, 明确调查的对象, 以及如何观察、 测量、记录和收集特定景观特征（图5)。 同样以摄影为媒介之一, 研究员们依据不同 的框架, 分别使用了黑白摄影、分类摄影、 全景摄影、延时摄影、全球定位系统同步、 样本测量拍照等方法。前往贡嘎山前, 研究 者们为各自的主题设计了所需工具及田野工 作框架, 并在特罗姆瑟的一处高山场地进行 了试验与改进。

\section{4 绕行中的田野工作}

研究员们在贡嘎山选择了一条绕行的调 查线路, 其最低点海拔为1 $200 \mathrm{~m}$, 最高点 为3 $800 \mathrm{~m}$, 起点是刚开通的高架高速公路 沪定段的出口, 终点是原高速公路石棉段的 入口。线路途经海螺沟冰川公园、高山科研 站, 以及磨西镇、新兴镇附近的彝族乡村。 此外, 在为期 10 天的实际考察中, 一些路段 因无法通行而必须绕行。预设的工作框架在 这种情况下帮助研究者们专注于景观调查, 同时保持了行程的机动性（图6)。

“水与能源” 主题的研究者制作了一盒 草图卡片, 用素描的形式记录了16个与水 景观有关的停留点, 有上游的冰川, 也有下

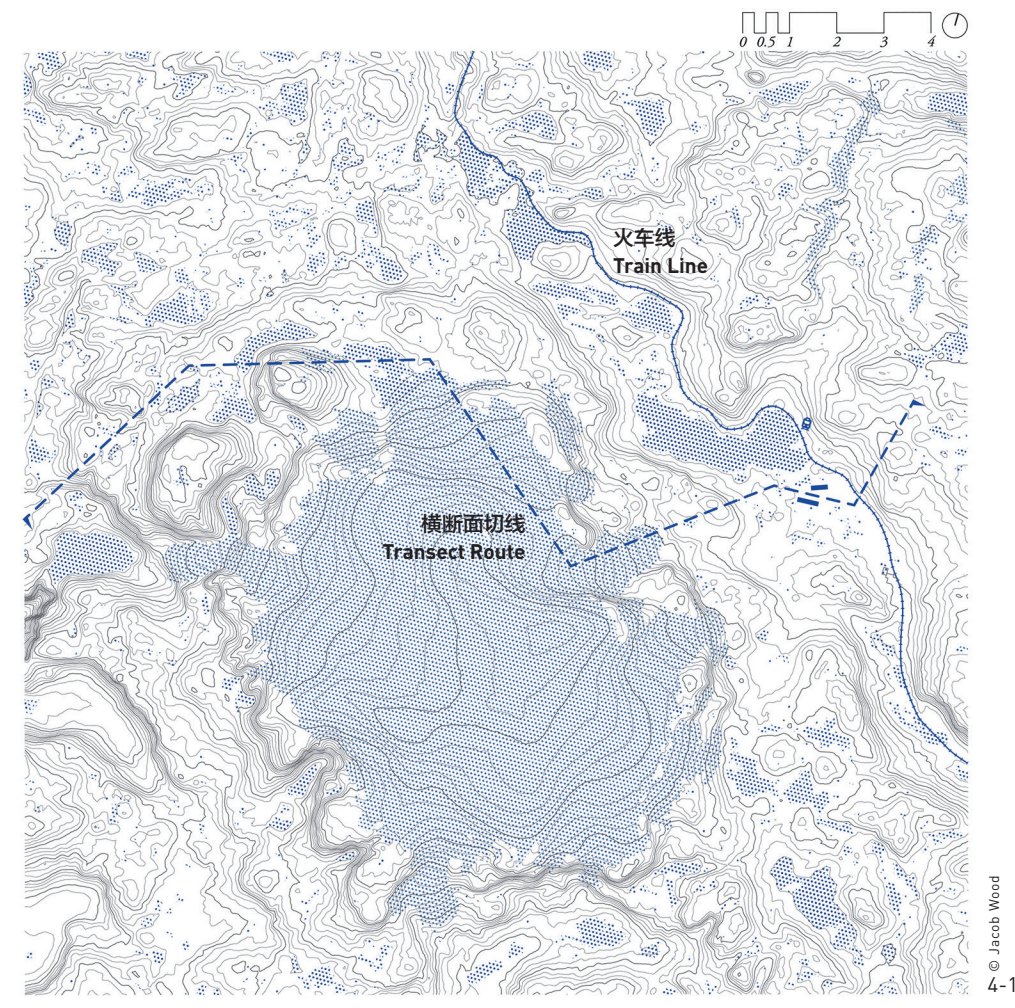

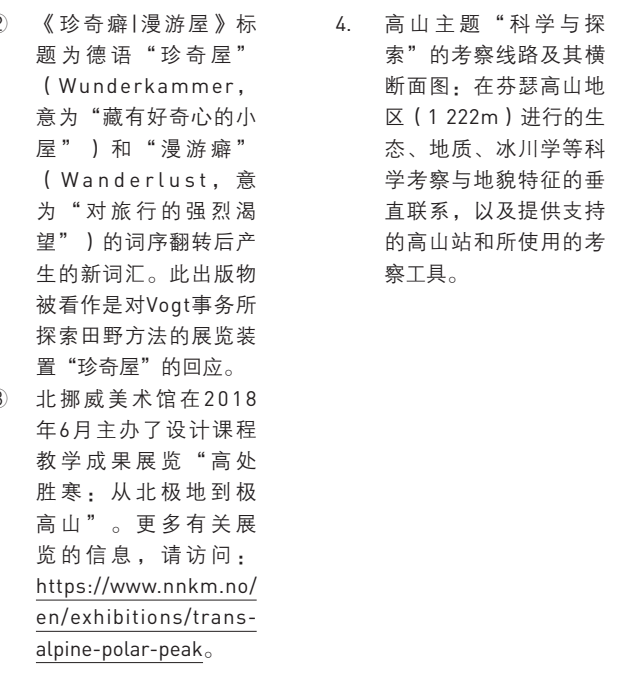
Mapping alpine topic in transect along a route: scientific land exploration, in the Finse alpine area $(1,222 \mathrm{~m})$ depicting the vertical dispositions of the landform in relation to ecolorical ecological, geological, and glaciological research supported by alpine station and research toolbox.


游电站大坝拦截而产生的广阔水域。“交通 与流动性” 主题的研究者运用分类摄影的方 式, 以特定的视角拍摄记录了4类12条道路 的环境、形式与材料特征。“食物与生产” 主题的研究者以连环插画故事的形式, 结合 横断面图与全景摄影, 记录了5 个乡村在混 合农业与牧业用地上进行的种植、晾晒、养 殖与贮存食品活动。“科学与探索”主题的 研究者以气象站为灵感, 设计了一个声音与 气象数据收集系统, 由气象卡片、录音装 置、GPS同步定位摄影构成; 收集地点包 括科学考察站、测量站与冰川在内的 41 个停 留点, 并在后期将声音展开为图像。“生态 与栖息地” 主题的研究者设计了一套包含标 尺板与防水袋的生态记录小册子, 收集了8 个停留地点的植物与矿物样本、绘制了生态 区横断面, 并将样本编号拍照后标记在断面 图中 (图7)。“旅游与风景体验”主题的 研究者拥有主观体验者与客观观察者双重身 份, 一方面将自己旅行体验中印象深刻的停 留点透过木质相框拍摄下来; 另一方面选择 若干个固定地点, 用延时摄影技术记录来往 旅行者的行为活动, 并进行叠加拼贴的后期 处理。

\section{5 在北极地策划贡嘎山}

经过收集与记录, 贡嘎山考察中的停留 点都与每个主题的景观线路串联了起来。回
到特罗姆瑟后, 每位研究者需要从贡嘎山的 田野工作地点中选出一个场地, 进行场所设 计或策划; 再从区域尺度上提出对景观线路 未来的构想, 从而在更大的尺度上思考该停 留点的设计意义。

“水与能源” 的卡片依次序排布, 组成 了一条研究者亲历的水景观路线。设计场地 选定为其中一个位于大渡河与高速悬桥交汇 点的蓄水水库。研究者将这个场地的陆地与 水域策划为能源景观公园, 作为大渡河游脜 路线的一部分，以此提升公众对能源生产所 导致的水景观变化的关注。

“交通与流动性” 中的盘山路大多具有 良好的视野与风景, 但对步行者并不友好。 研究者通过分类摄影对这一现象进行了记 录, 并选取了一条连通磨西镇与乡村的路径 为研究对象, 提出了5种从空间上改进步行 道与路旁休㲡观景设施的建议措施。这一路 段作为众多新建盘山公路的缩影，为探讨其 中的道路矛盾提供了启示。

“食物与生产”主题线路将一系列村 庄串联在了一起。在位于城镇与冰川公园之 间的新兴村, 研究者设计了一个路旁食品中 心, 为村民与旅行者们共用, 以展现当地的 食物文化与生产、制作过程。

“科学与探索” 主题线路以冰川中不同 区域的声音记录了冰川消退的路径。研究者 在现有冰川栈道的高处设计了一个冰川声域 体验场所，用以接收从目前无法到达的贡嘎
山区传来的冰川录音。冰川声音的记录点可 成为衡量未来冰川消退的“刻度标尺”。

根据生态小册子的记录, “生态与栖息 地” 的取样区域构成了一条自然教育路线，可 供自然旅行者与科学家们进行探索。研究者 在海螺沟冰川末端的节点设计了一个空间框 架, 用以测量、展示地貌动态与植被演替。

“旅游与风景体验”的记录照片使研究 者注意到冰川栈道上人们的着装, 进而意识 到, 旅行者的实际准备往往不足以支撑他们 探索荒野的愿望。于是他设计了一个徒步露 营体验体系, 由三个层层递进的支持设施系 统组成; 未来, 这个系统将扩建至贡嘎山与 横断山区更广的徒步网络中。

最后, 课程指导教师策划了“高处胜 寒” 展览 ${ }^{3}$, 将北挪威美术馆里的一个展览 空间转变为设计课程的反思场所, 藉此创造 一个北极地与极高山的对话平台。“田野之 桌”（图8）上陈列着田野工作的实体工具 和成果。墙面空间展示了关于贡嘎山的场所 设计方案和路线的构想（图9，10），对应 着6个主题的挪威高山绘图。挪威北部与贡嘎 山的投影图像则模糊了两个相隔遥远、文化 截然不同的地理区域的边界。在跨地域探索 高山路线的过程中，表现工具（高山绘图） 帮助研究者们客观地认知高山, 体验工具 （田野框架）协助研究者们主观地融入景观 路径之中，实地考察则成为了未来停留场所 设计与路线策划的参考基础。LAF

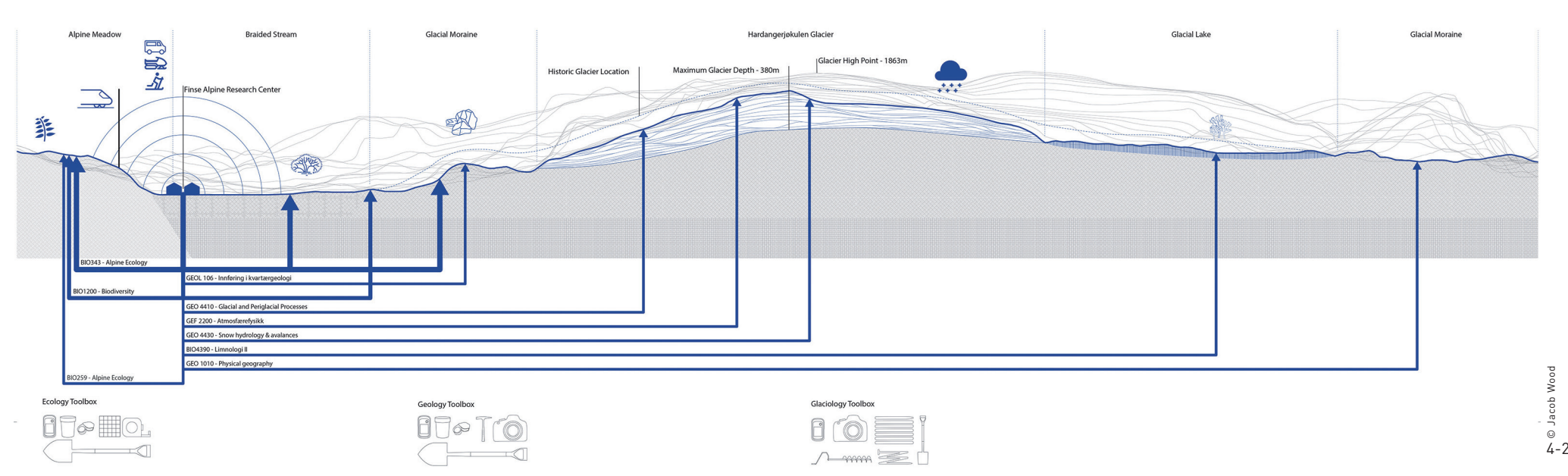




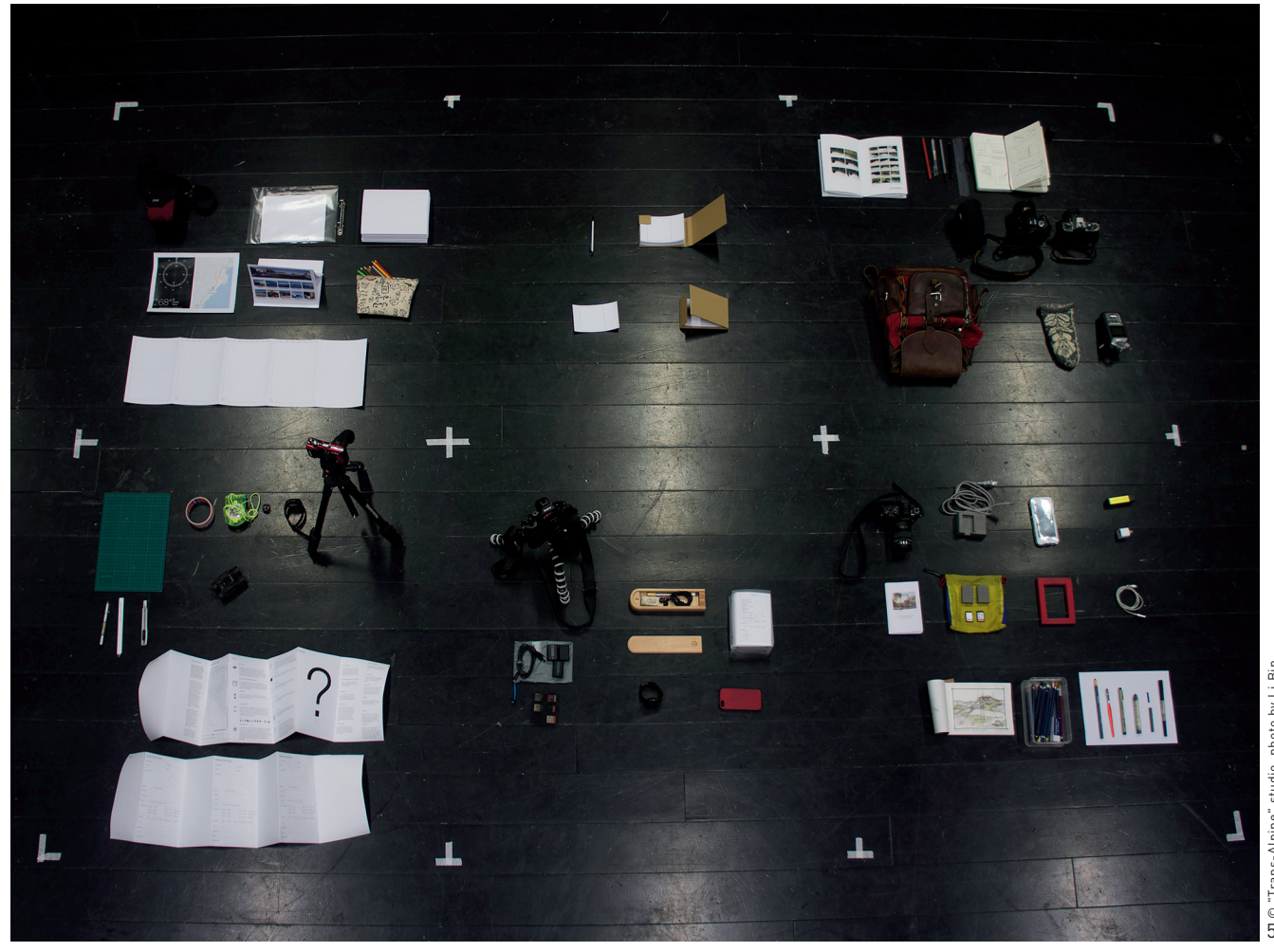

\section{Introduction}

A type of geographies in China featuring geomorphological resources has become a new travelling destination for urban dwellers. Elevated from surrounding plains, these geographies take a form of alpine zones and high mountains, overlay ecological belts, and diversify cultural landscapes. In recent years, alpine landscape as a resource has been occupied by new emphases ${ }^{[1]}$ : infrastructure is updating on account of the burgeoning travel culture, villages and towns are developing into service zones, and the regional landscape is therefore in drastic transformations. In the Hengduan Mountain Ranges of Southwestern China, there exist many alpine regions as such and one of them is Mount Gongga, the highest and most prominent mountain in Sichuan Province (Fig. 1).

We started to inquire into Mount Gongga from Troms $\varnothing$, an Arctic city in Northern Norway, in form of a design studio "TransAlpine: From the Polar to the Peak" ${ }^{(1)}$ at the Oslo School of Architecture and Design (AHO). As researchers from outside, students would have to transcend the geographical and topographical barriers to step into the "white-spot" of a Chinese alpine territory, so to imagine its future landscape routes. Contemplating from a distance, the design studio began with mapping out and understanding alpine landscape characteristics in the Norwegian context through different topics, particularly by drawing transects. Then in physical interactions, a fieldwork framework that was developed by individual researchers guided observation and landscape experience along a designated Mount Gongga route. The design outcomes generated through this process were curated and exhibited at Nordnorsk Kunstmuseum - the museum of
1) "Trans-Alpine: From the Polar to the Peak" was the 2018 spring term first-year Master of Landscape Architecture design studio at the Oslo School of Architecture and Design, based at the Troms Academy of Landscape and Territorial Studies in the Arctic city of Tromse. The studio concept and The studio concept and course oulline were set up by Li Bin; teaching team: Li Bin, Hannes Zander, and Biljana Nikolić; student researchers: Sanaz Akbari Koli (food and production). Oskar Hjellbakk lecosystem and natural habitat), Aztrid Novillo (water and energy). Mia Thun Itransportation Ma Thun llransportation and mobility), Patrick landscape experiencel, and Jacob Wood Iscientific land exploration). fine art in Northern Norway.

\section{The Alpine Difficulties}

“Once the Mount Gongga between Yalong and Dadu River was marked as a white spot on maps, written 'un-surveyed.' Some maps covered its location with imaginary mountain drawings," ${ }^{[2]}$ cartographer Eduard Imhof depicted Mount Gongga as such in his book "Die Großen Kalten Berge von Szetschuan" (The High Cold Mountain in Sichuan). In the year 1930, Imhof was a member of a Chinese-Swiss expedition team which aimed for a geologic and cartographic survey. Researchers carried on measuring and recording tools, and walked in valleys and on passes around Mount Gongga. It was a compromised circuit between the topography and the measurer, as it was the closest route to the summit at relatively low elevations. The "white-spot" region from 
then on was drawn onto a map. Eighty years later, this alpine route has transformed into a network of elevated highways, scenic roads, hydropower infrastructures, scientific practice facilities, glacier parks, and tourist towns - an urbanized landscape is increasingly emerging.

Alpine topographic information learned by a landscape researcher from a map is static and "accurate." A researcher can experience more tension between the individual and the high mountain through walking and acquire local knowledge by working on site. Being exposed to an alpine environment can be challenging to humans in terms of orientation, vista, and body performance, not to mention being very often forced to take a detour. Extreme in prominence, a high mountain massif stretches its landscape layers in elevations, meanwhile condensing them horizontally. From semi-arid valleys of the Dadu River at $1,000 \mathrm{~m}$ to the $7,556 \mathrm{~m}$ summit covered by permanent snow, the bioclimatic zones of Mount Gongga shift from a subtropical zone to an ice desert within a distance of just 30 kilometers (Fig. 2). Dramatic topography, compromised routes, and vertical, overlaid, and dynamic landscapes shape high mountains like Mount Gongga and turn it into a difficult research target.

\section{Tools for Landscape Inquiries}

“This tension between us and the landscape is a significant strain that cannot only be grasped visually and abstractly. As such, representational and non-representational approaches to geography are intertwined in order to more holistically evaluate the friction between the individual and their environs, suggesting the importance of mountainous topographies within the realms of human experience and humanities. ${ }^{[3]}$ The design studio experimented with a hybrid approach to inquire into high mountains and Mount Gongga, hybridizing distance and engagement, alpine mapping and fieldwork, as tools of landscape representation and experience.

The concept of "high places" defined by geographers Denis Cosgrove and Veronica della Dora supported alpine research across geographies that high latitudinal and high altitudinal regions share various climatic, geomorphic and biotic characteristics, and from perspectives of cultural geography, they fall into " regions of difficulty." ${ }^{[4]}$ This means that landscape scenes occurring in Chinese high mountains exist accordingly in Norwegian alpine zones. Categorizing these characteristics can assist on comprehending varied layers of alpine landscapes. Therefore, the design studio defined six topics to depict the alpine: water and energy, transportation and mobility, food and production, scientific land exploration, ecosystem and natural habitat, and tourism and landscape experience.

We experimented with mapping out these topics in plans and transects, and the Norwegian alpine zones served as a base map on which researchers traced themes in a territorial scale (Fig. 3). The studio required each researcher to pick up a 20-kilometer area upon reading the planar map, and draw a transect showing a specific topography, vertical space, and landscape dynamics (Fig. 4). "Such a shift not only implies a change in the representation of space; it also requires a different turn of mind and a different relationship to space. The map requires a global vision, whereas the transect is based on a route, a directionality that can be sharp." ${ }^{[5]}$ Transects are able to represent the vertical dispositions of alpine characteristics, the surface and subsurface processes, the spatial and time dynamics of landscape.

After territorial explorations through the tool of mapping, the design studio moved to phases of fieldwork. In "Wunderlust / Wanderkammer," Güther Vogt edited the landscape fieldwork process into an act

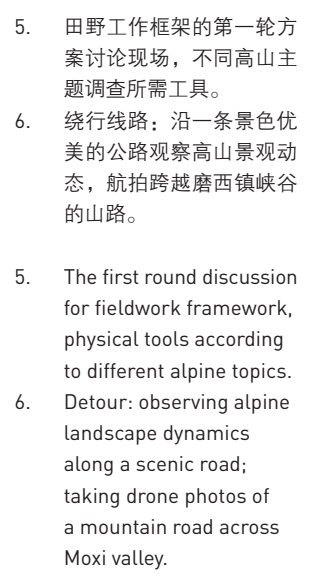

5. The first round discussion for fieldwork framework physical tools according to different alpine topics.

6. Detour: observing alpine landscape dynamics along a scenic road; taking drone photos of a mountain road across Moxi valley.
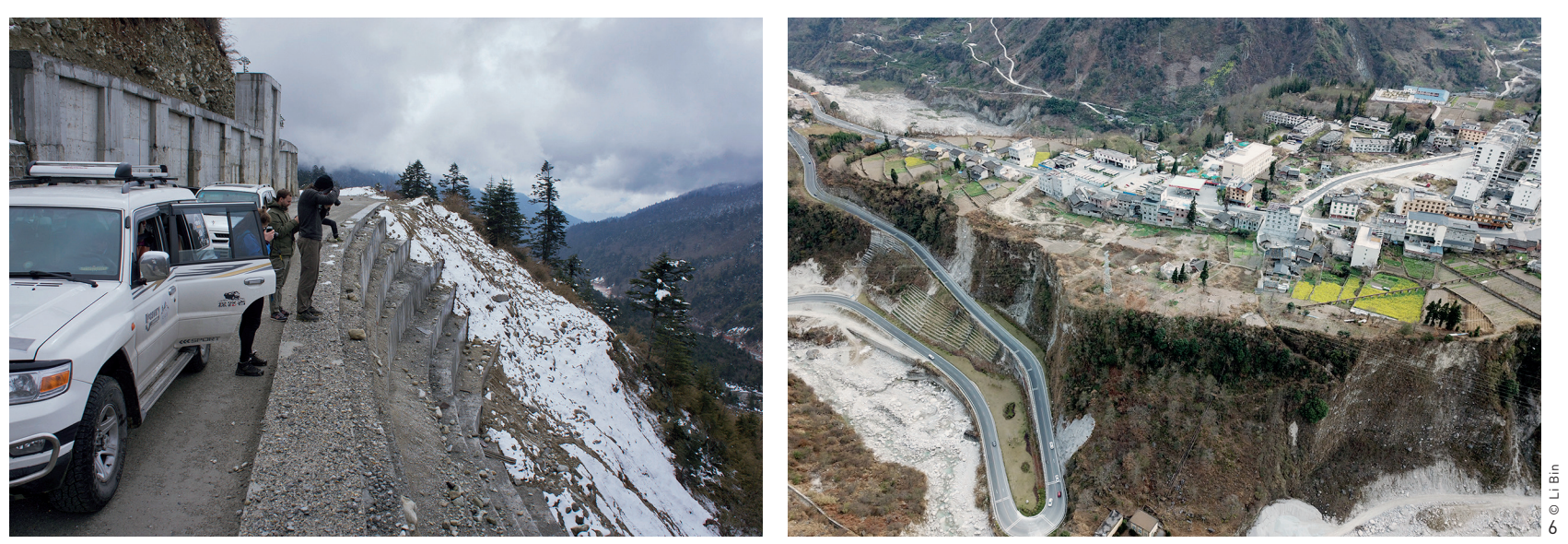


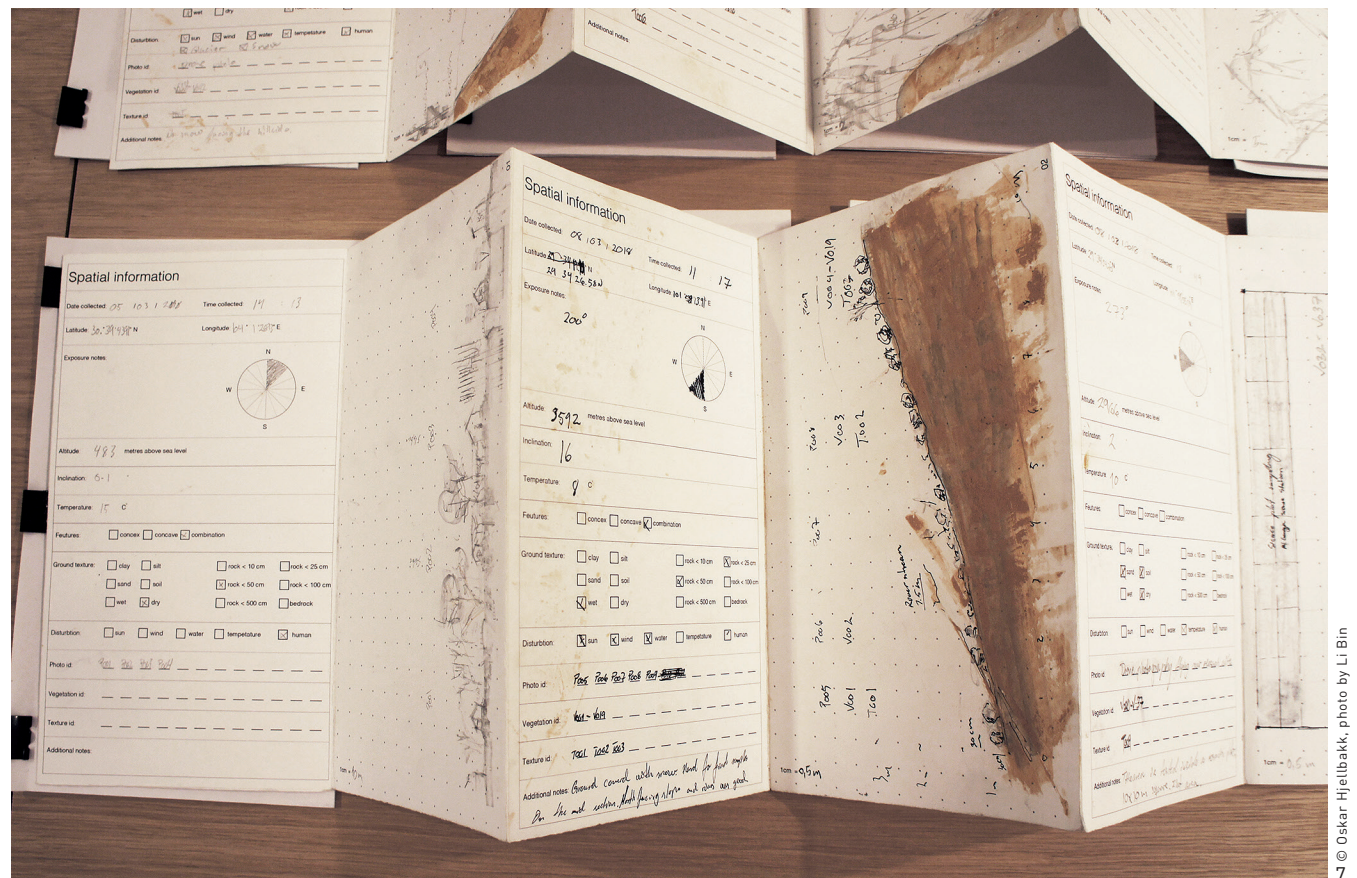

of collecting, recording, and translating ${ }^{2}$. This publication is not a regular book but takes the form of cards, folded booklets, and cardboard file holders to drop a hint of how field tools could look like. Field knowledge collected through a wanderlust journey was recorded and organized in a "cabinet of curiosity," which later was translated into a design. A fieldwork tool is more than a medium, a device or an equipment. The tool is a designed instrument or framework, a workflow of one or multiple media. The field tool facilitates a personal and subjective approach to engage with and immerse in the landscape; it helps in building up a body of data to comprehend and explain specific conditions and processes, while maintaining resilience during a field trip. A physical tool should be able to be well preserved in an outdoor environment. In the studio, researchers were asked to define a working concept of what exactly they would examine and how they would intend to observe, measure, record, and collect certain landscape features (Fig. 5). All researchers took photography as one of their media; however, according to their individual framework settings, they used black and white photography, cataloging techniques, panorama, time-lapse recordings, GPS tracking formats, or sample measuring techniques. Before traveling to Mount Gongga, researchers designed the tool and framework for individual topics, and found an alpine site in Tromsø for experiment and improvement.

\section{Fieldwork along a Detour}

The studio took a detour in Mount Gongga, between elevations of 1,200 m and $3,800 \mathrm{~m}$. The route began at the exit of the new elevated highway Luding Session, and ended at the old highway Shimian entrance. The detoured parts included the Hailuogou Glacier Park, Gongga Alpine Research Stations, and Yi villages around the town of Moxi and Xinxing. Some parts were inaccessible and we had to make some extra detours during the ten days' field trip. The previously developed fieldwork tool assisted researchers to

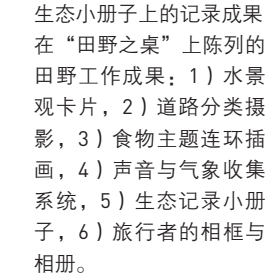

focus on landscape inquires, and retained resiliency to the journey (Fig. 6).

The researcher concerned with "water" created a box of drawing cards, sketching out 16 pausing sites, which included upstream glaciers and downstream vast water surface areas resulting from hydropower dams. The "transportation" researcher defined a workflow that photographed road characteristics, categorizing 12 sessions of 4 road types according to their environs, forms, and materiality. The researcher exploring "food" chose to use a storyboard and illustration approach that combined sketches with transects and panoramic photos, documenting the situation of 5 villages in planting, drying, breeding, and preserving food, and their mixing use of arable land and pasture. Inspired from weather station components, the "science" researcher developed a sound and weather data system that composed weather cards, sound collecting devices and GPS tracking photography; the researcher recorded 41 sound clips including those from research stations, measure facilities and glaciers, and
Wunderlust/ Wanderkammer was a title reformed from German words Wunderkammer - a cabinet of curiosity, and Wanderlust - a strong desire of travel. This publication was an echo of a "Wunderkammer" installation developed by Vogt office for exploring field method. 
later expanded the sounds into images. The "ecosystem" researcher produced a set of booklets together with a measure mat and a waterproofing pouch; the researcher collected flora and mineral samples in 8 areas, drew a transect for each, photographed samples on the mat, and then numbered and marked the sample plots onto the transect (Fig. 7). The researcher examining "tourism" combined roles as a tourist and as an observer; the researcher photographed through a frame in strong experiential moments and at certain locations, changed to a time-lapse and post-collaging technique to document tourists' behavior.

\section{Curating Mount Gongga in the Arctic}

Through collecting and recording, pauses were connected to each topic's landscape route. After the studio traveled back to Tromsø, we required each researcher to find an individual site for intervention, which could be chosen from any of the fieldwork spots in Mount Gongga, to design or curate their selected sites as an act of place-making. In addition, the researchers were asked to imagine future landscape routes in a territorial scale, and thereby considered the large-scale significance of the place's design.

Water and energy cards sequenced a route of waterscape from which the researcher experienced and selected the site - a reservoir at the intersecting point of the Dadu River and a suspended highway bridge. The researcher proposed to transform the site's land and water surface into an energy park as part of a recreational route along the river, to raise public awareness for water landscape changes as a consequence of energy production.

Most mountain roads possess pleasant vista and scenery but are not friendly to walkers. This phenomenon was observed through a photographic catalog and the

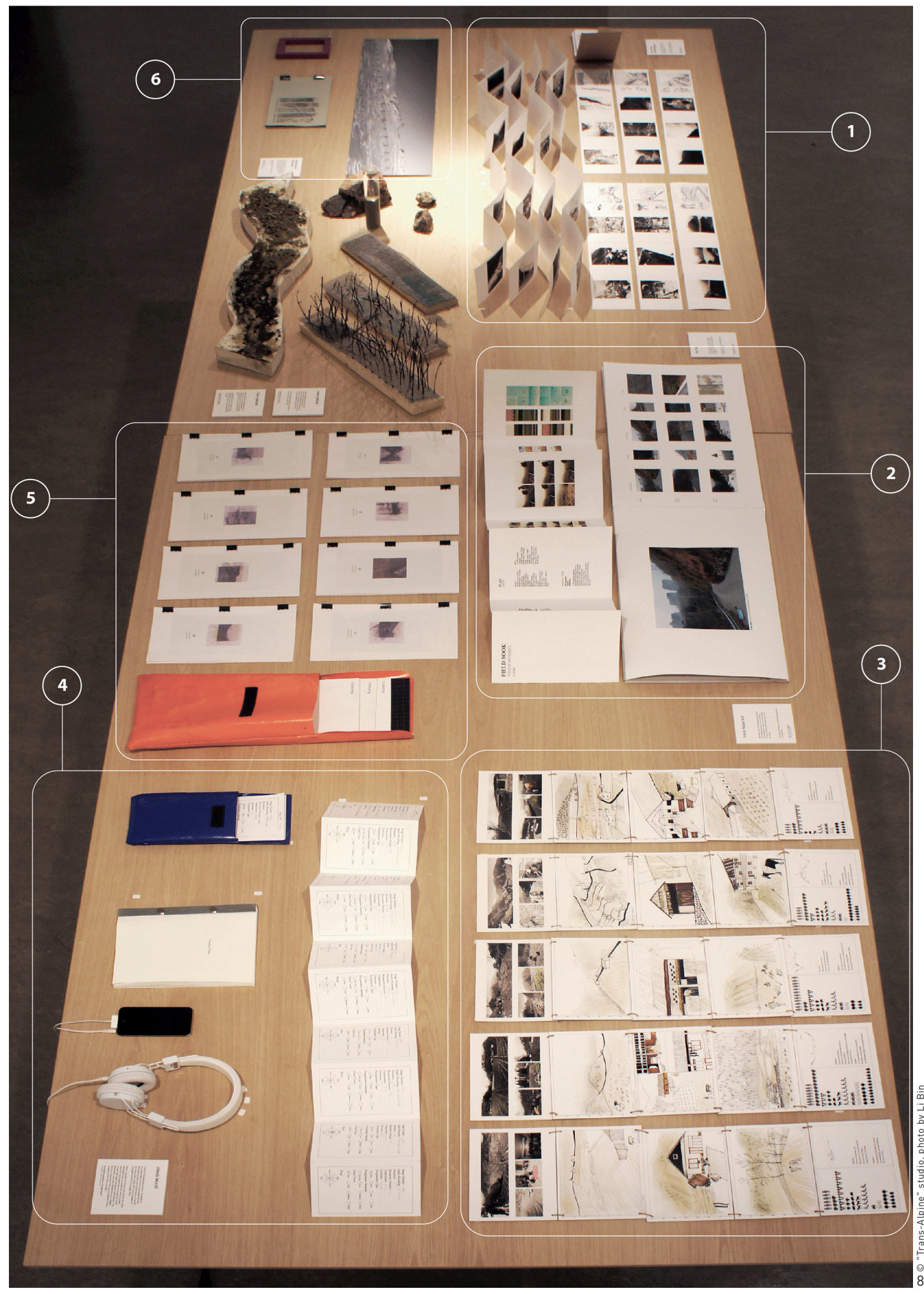

researcher picked up one road between Moxi Town and an Yi village, suggesting 5 spatial possibilities to improve pedestrians and roadside pauses. This road session served as a miniature case study of conflicts that appear on most of the newly constructed mountain roads.

The story of food and production linked together a group of villages. In Xinxing Village sitting between a town and a glacier park, the researcher designed a roadside food center where local food cultures around 

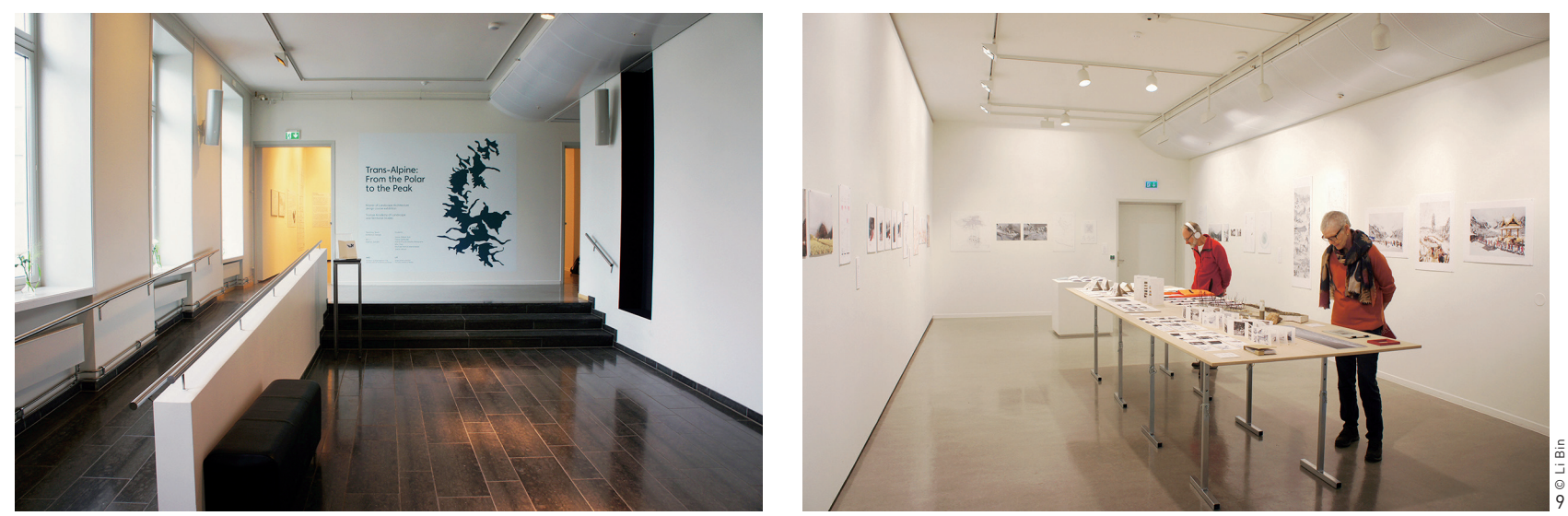

3) Nordnorsk

Kunstmuseum hosted the design studio final exhibition "TransAlpine: From the Polar to the Peak" in June 2018. For more information, please visit https://www.nnkm.no/ en/exhibitions/transalpine-polar-peak. producing and processing could be shared by the villagers themselves as well as visitors.

In the "science" topic, sound clips from various glaciers recorded a path of glacial retreat. The researcher designed a glacial sound field at the high point of an existing glacier trail, to receive glacier records that transported from currently inaccessible parts of Gongga. The recording locations would become measures of retreat in future.

According to fieldwork booklets, the natural habitat sample areas suggested a route of nature education, in order to provide opportunities for nature explorers and scientists. At the terminus of

Hailuogou Glacier, the researcher designed a spatial framework for measuring and displaying geomorphologic dynamics and plant successions.

The observing photos made the tourism researcher notice the urban outfit travelers wearing on glacial trails, and the desire to wilderness could be stronger than the preparation. The researcher then designed a trekking system that composed of threetiered supporting infrastructures. In future this system would apply to a broader trekking network in Gongga and Hengduan Ranges.

The studio instructors curated the
“Trans-Alpine" exhibition ${ }^{3}$ in the final stage, transformed an exhibition space at the Nordnorsk Kunstmuseum into a place for reflection, and by doing so created a dialogue between the Polar and the Peak. On a "Field Table" (Fig. 8) seated there physical tools and their outcomes from the fieldworks. The wall space displayed place design and route curation of Mount Gongga (Fig. 9, 10), corresponding to the six thematic alpine mappings of Norway. The projected images blurred the boundary of the two geographies and cultures. In the experimental process across geographies, the representational tool (alpine mapping) generated an objective perspective in approaching alpine landscapes in general; the experiential tool (fieldwork framework) assisted the researchers to immerse into a landscape travel. The field trip turned into the reference map for curating pauses and routes in the future. LAF

\section{REFERENCES}

[1] Vogt, G. (2015). Landscape as a Cabinet of Curiosities. Zürich: Lars Müller Publisher.

[2] Imhof, E. (1974). Die Großen Kalten Berge von Szetschuan. Zürich: Orell Füssli Verlag.

[3] Goetsch, E., \& Kakalis, C. (2018). Introduction. In C. Kakalis \& E. Goetsch (Eds.), Mountains, Mobilities and Movement (pp.112). London: Palgrave Macmillan.

[4] Cosgrove, D. \& Della Dora, V. (2009). Introduction. In D. Cosgrove \& V. Della Dora (Eds.J, High Places: Cultural Geographies of Mountains, Ice and Science (pp. 1-16). London \& New York: I.B.Tauris \& Co Ltd.

[5] Pousin, F. (2012). Urban Cuttings: Sections and Crossings. In C. Girot \& F. Truniger (Eds.), Landscript 1: Landscape Vision Motion (pp. 101-117). Berlin: Jovis Verlag GmbH.
9. “高处胜寒”展览现 场, 北极地与极高山的 介绍。

10. 学生们提出的贡嘎山场 所设计和路线策划方案

9. "Trans-Alpine" exhibition, introduction of the polar and the peak.

10. Place designs and route curations by students for Mount Gongga
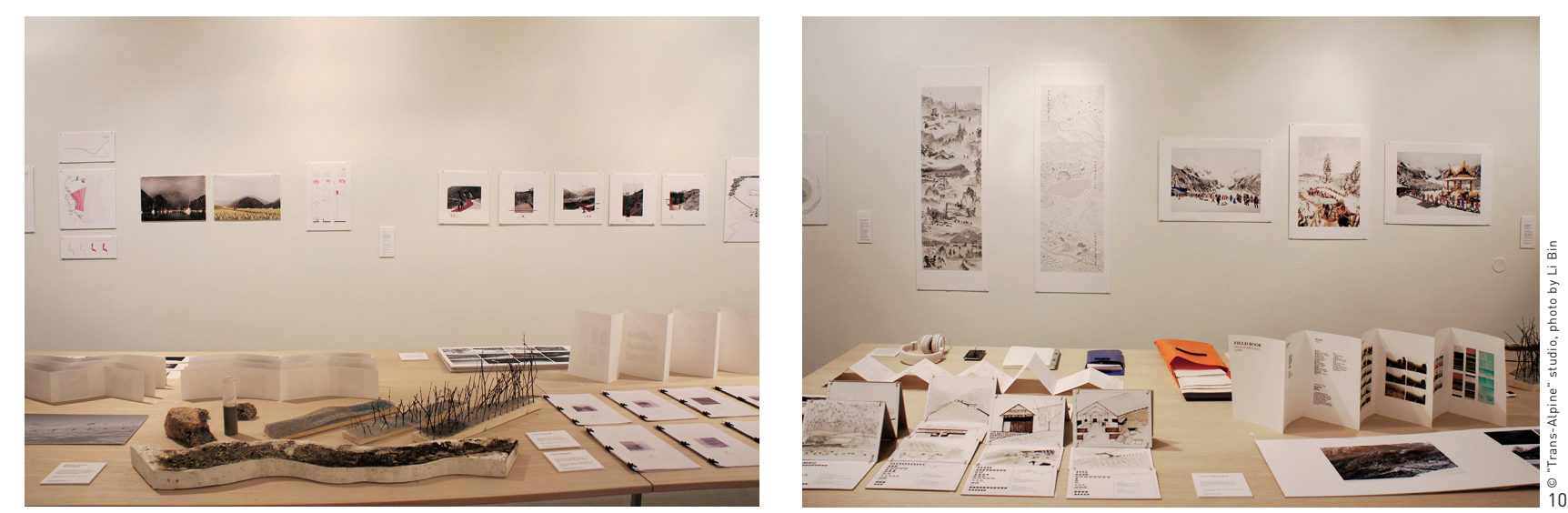